\title{
AS PERSONAGENS VISTAS COMO LOUCAS \\ PELO 'OLHAR REPUBLICANO' \\ UMA APROXIMAÇÃO ENTRE ANTÔNIO CONSELHEIRO \\ E POLICARPO QUARESMA
}

Caroline Brizon*

Marília Cardoso**

\section{Resumo}

Este trabalho pretende analisar as figuras de Antônio Conselheiro e Policarpo Quaresma enquanto construções dos escritores Euclides da Cunha e Lima Barreto. Considera-se o contexto cientificista presente no século $\mathrm{XX}$ e o modo como este influenciou a composição das personagens. Ademais, é feito um paralelo entre esses 'intelectuais dissidentes' que foram até as últimas consequências para defender seus ideais e morreram sob o estigma da loucura.

\section{Palavras-chave}

Literatura. Policarpo Quaresma. Antônio Conselheiro. Lima Barreto. Euclides da Cunha.

É raro encontrar homens assim, mas os há e, quando se os encontra, mesmo tocados de um grão de loucura, a gente sente mais simpatia pela nossa espécie, mais orgulho de ser homem e mais esperança na felicidade da raça.

\section{Lima Barreto}

\section{1) As figuras de Lima e Euclides}

Em 1916, o escritor Lima Barreto, em uma entrevista ao jornal A época, disse que O triste fim de Policarpo Quaresma, publicado como livro no ano anterior, pretendia "mostrar a puerilidade de muitas das nossas pretensões brasileiras" (BARRETO, 2006, p. 1). De fato, Policarpo é uma figura "visionária", como é chamado no livro por Floriano Peixoto, fruto da imaginação de um escritor que era preocupado com a sociedade em que vivia e que via a literatura como meio de mudança social (GERMANO, 1995, p. 42). Assim, da figura do major, é possível depreender questões que afetam a sociedade

\footnotetext{
* Graduada em Jornalismo pela PUC-Rio e graduanda em Letras Bilíngue (Inglês e Português) e Respectivas Literaturas na PUC-Rio.

** Doutora pela PUC-Rio, professora aposentada da UERJ, professora em exercício da PUC-Rio; pesquisadora 1D do CNPq; no momento, desenvolve trabalhos sobre arquivos literários, processos de construção de escritas e atividades artístico-culturais consideradas periféricas.
} 
brasileira, como a "idealização de reformas em uma sociedade estática", a "cultura obtida em gabinete" e a necessidade de se ter um "título de doutor como adorno social indispensável" (PÓVOA, 1983, p. 7).

De igual modo, a preocupação social é notável na obra Os sertões, de Euclides da Cunha, publicada em 1902. O livro é o resultado da experiência do escritor na Guerra de Canudos, ocorrida em Canudos, no interior da Bahia. De agosto a outubro de 1897, Euclides da Cunha foi enviado para o local como correspondente do jornal O Estado de S. Paulo a fim de realizar a cobertura da guerra. De início, o repórter tratou o conflito como um retrocesso, em que "os combatentes refluíam à barbárie dos homens das cavernas" (VENTURA, 2003, p. 150). No entanto, ao acompanhar o avanço das tropas, Cunha pôde ver "o abismo que tragava a vida dos soldados e conselheiristas, atirando no vácuo a sua fé no progresso e na República" (VENTURA, 2003, p. 150). Nos artigos feitos para os jornais, ele omitiu a crueldade vivenciada em Canudos e as decepções com o sistema político, situação que foi remediada em Os sertões.

Cinco anos mais tarde, Euclides denunciou, em Os sertões, a campanha militar como crime e fez a confissão de culpa da omissão de suas reportagens, ao mencionar os fatos sobre os quais antes silenciara: a degola dos prisioneiros e o comércio de mulheres e crianças. Criticou a hipótese de conspiração política, apoiada por grupos monárquicos e por países estrangeiros, que havia justificado o massacre (VENTURA, 2003, p. 175).

Em sua obra, Euclides vai tratar da figura mais emblemática do confronto: Antônio Vicente Mendes Maciel, mais conhecido como Antônio Conselheiro. O beato é descrito pelo escritor como um "anacoreta sombrio" com cabelos que iam até os ombros, "barba inculta e longa", "face escaveirada", "olhar fulgurante" e monstruoso. Segundo Cunha, Conselheiro andava "dentro de um hábito azul de brim americano, abordoado ao clássico bastão, em que se apoia o passo tardo dos peregrinos...” (CUNHA, 1973, p. 127128).

O fato de Conselheiro ser uma personagem histórica é o principal ponto que o diferencia de Policarpo Quaresma. Euclides, em seu ensaio artístico, traz para a escrita, por exemplo, documentos e pesquisas que retratavam o beato. Porém, mesmo utilizando da ciência positivista e buscando a objetividade, o autor ultrapassa o saber científico, negando-se a seguir à risca o que este prescrevia. Em contrapartida, Policarpo é parte das elucubrações de Lima somente, ainda que este tenha se baseado na observação crítica da história recente para construir a figura 'pixotesca' do major. A personagem criada por 
Lima representa os anseios e ideais do próprio autor em sua ficção romanesca e serve como forma de questionamento do poder da ciência usada como ferramenta por Euclides para a formação de Os sertões. Dessa forma, ambas as obras funcionam como tentativas de retratar a cultura brasileira na virada do século XIX para o XX e trazem questões relevantes para a época em que foram concebidas. De um lado, a Guerra de Canudos e a República; de outro, a Revolta Armada e o governo de Floriano Peixoto.

De acordo com Germano, tanto Os sertões como $O$ triste fim de Policarpo Quaresma podem ser vistos como livros que tratam do "processo de descolonização" da sociedade brasileira, abordando, por exemplo, "o progresso desordenado" e a "opressão a que o povo é submetido". Para a pesquisadora, as figuras de Policarpo e Conselheiro são visionárias. Enquanto uma representa a "loucura de um projeto promissor, mas perigoso à ordem capitalista", a outra representa a "quimera de um patriotismo ingênuo, desligado da realidade concreta" (GERMANO, 1995, p. 48-49).

Pretende-se, neste trabalho, estabelecer uma relação entre Policarpo e Conselheiro - tal como foi concebido por Euclides em seu ensaio - enquanto personagens que foram tratadas como loucas pelo 'olhar republicano'. O termo é usado aqui como referente ao pensamento característico do século XIX e início do XX, quando a República brasileira lutava as suas primeiras batalhas, em que se valorizava a ciência, a objetividade e a racionalidade. A partir desse olhar, ressalta-se que ambas as personagens estavam à margem da sociedade em que viveram, foram retratadas como idealistas, ingênuas e suas pretensões as levaram a finais trágicos. De certa forma, elas desafiaram as autoridades do seu tempo e foram até as últimas consequências. Sendo tratadas como fanáticas por conta de seus ideais, elas abriram mão da própria vida em nome do que acreditavam.

\section{2) Os crânios}

Euclides da Cunha, nas páginas finais de Os sertões, disse que a "ciência" analisaria o crânio de Antônio Conselheiro e diria a "última palavra", pois acreditava-se que nele se veriam as "linhas essenciais" do "crime e da loucura" (CUNHA, 1973, p. 393). Essa visão cientificista permeia toda a obra, visto que Euclides era um estudioso das ciências do seu tempo. Na época, estas estavam apoiadas em teorias como a do darwinismo social, que considerava que alguns homens nasciam superiores a outros (BOLSANELLO, 1996, p. 154), e a da "Eugenia", que pregava o estímulo à reprodução das "raças superiores”, ou seja, os brancos (DEL CONT, 2008, p. 202). 
É necessário, porém, ressaltar que, apesar de o autor de Os sertões se render em certos pontos a essas postulações, ele também assume um posicionamento crítico com relação às ciências. Desde a primeira república, a procura por uma identidade ética única se tornou preocupante para intelectuais como Euclides, que acreditavam na degenerescência do mestiço e na superioridade dos brancos. Na obra, é retomado o tema da existência de um "tipo étnico" característico do Brasil (MUNANGA, 1999, p. 52), o "cerne" do país, que, para Euclides, seria o mestiço do interior do Norte. Contrariando as teses de "embranquecimento", ele defende que o jagunço "estaria se constituindo em raça e, no futuro, seria capaz de desenvolvimento mental" (MUNANGA, 1999, p. 60). Nesse ponto, vê-se a inversão do darwinismo social quando o engenheiro conclui que a derrota dos jagunços foi a vitória de uma civilização "em tudo inferior à raça que dizimara" (PENNA, 2015, p. 59).

Como aponta Bovo, os jagunços, para o engenheiro, "vão tomando a feição de heróis mestiços, de hércules-quasímodos", mas o seu líder é tratado como "um caso de atavismo, uma monstruosidade gerada pelas contingências biológicas, geográficas e históricas" (BOVO, 2007, p. 62). Para Euclides, o beato dono de "um misticismo feroz e extravagante" de raças inferiores e menos evoluídas foi "para a história como poderia ter ido para o hospício" (CUNHA, 1973, p. 120). O religioso se encontrava, assim, na margem entre loucura e sanidade.

\begin{abstract}
Antônio Conselheiro foi um gnóstico bronco [...] paranoico indiferente, este dizer, talvez, mesmo não lhe possa ser ajustado, inteiro. A regressão ideativa que patenteou, caracterizando-lhe o temperamento vesânico, é, certo, um caso notável de degenerescência intelectual, mas não o isolou - incompreendido, desequilibrado, retrógrado, rebelde no meio em que agiu. [...] A sua frágil consciência oscilava em torno dessa posição média, expressa pela linha ideal que Maudsley lamenta não se poder traçar entre o bom senso e a insânia. Parou aí indefinidamente, nas fronteiras oscilantes da loucura, nessa zona mental onde se confundem facínoras e heróis, reformadores brilhantes e aleijões tacanhos, e se acotovelam gênios e degenerados. Não a transpôs. Recalcado pela disciplina vigorosa de uma sociedade culta, a sua nevrose explodiria na revolta, o seu misticismo comprimido esmagaria a razão (CUNHA, 1973, p. 146-148).
\end{abstract}

Dessa forma, a visão cientificista, evolucionista e determinista é importante para se compreenderem os próprios apontamentos de Euclides sobre o líder de Canudos, Antônio Conselheiro. O autor vai retratar aquela sociedade como "miserável, ignorante, fruto do abismo cultural entre o sertão/barbárie e o litoral/civilização" (BOVO, 2007, p. 9). A preocupação com o meio também leva o escritor a estudar a história da personagem. 
Antônio Vicente Mendes Maciel é, então, apresentado como um "adolescente tranquilo e tímido, sem entusiasmo". Ele teria se isolado da família devido à rigidez do seu pai e teve uma vida tranquila e "correta". Cuidou de três irmãs solteiras, abrindo mão de si mesmo durante um período. Após o casamento delas, ele também procurou alguém para se casar, mas o relacionamento teve um final trágico, visto que a esposa foi "raptada" por um policial. Essa situação causa o seu afastamento e a procura por lugares "onde ninguém conheça sua história e saiba da vergonha que a mulher lhe causou" (SOUZA; CÂNDIDO, 2016, p. 17)

Euclides se baseou em "profecias apocalípticas”, que pensava serem do Beato, para tratar Canudos como um "movimento sebastianista e messiânico", cujo objetivo era a espera pelo retorno do rei português D. Sebastião, que derrotaria a República e restauraria a monarquia. Segundo Ventura, o escritor "projetou" sobre Conselheiro seus temores: irracionalidade, sexualidade, caos e anarquia com o objetivo de formar uma personagem guiada "por forças obscuras e ancestrais e por maldições hereditárias, que o levaram à insanidade e ao conflito com a ordem”. Sendo assim, a personagem de Euclides era contra a República, "que via como a personificação do Anticristo", e tinha uma postura crítica com relação ao casamento civil (VENTURA, 1997, p. 166).

\section{3) O triste fim}

O jornal A época, ao fazer uma crítica sobre $O$ triste fim de Policarpo Quaresma, disse que Lima era, na verdade, um "descriptor", pois sua obra é mais de "análise do que de arte" (1916, p. 2). É dessa preocupação com a crítica social, da puerilidade, do ufanismo e de um toque autobiográfico que nasce uma figura emblemática: o major Policarpo Quaresma.

Homem tímido, Quaresma era um nacionalista e ufanista que se interessava por estudar a cultura do Brasil, por isso vivia mergulhado em livros. Era um funcionário respeitado do Arsenal de Guerra, mas constante motivo de chacota por conta de seus discursos exaltados sobre as grandezas do país. Morava com sua irmã Adelaide, seguia uma rotina extremamente metódica e tinha como marca a ingenuidade, o que o levou a ser sentenciado à morte. Somente ao fim de sua vida ele percebe que a pátria pela qual lutara era uma mera ilusão.

Ao fazer um estudo etimológico do nome da personagem, Silviano Santiago mostra que a obra, já estruturada por "ganchos", tem ainda outra redundância. Segundo 
ele, Policarpo tem um triste fim, pois "é de nenhum fruto e é também de pulso fraco e é ainda um idealista que não consegue limpar a erva ruim da sua plantação". Além disso, a palavra quaresma se refere aos quarenta dias que remetem ao sacrifício de Jesus, "sinal que indica", segundo Silviano, "o caminho em vão do bode expiatório" (SANTIAGO, 1982, p. 174).

Com seu triste fim decretado em um título que pode ser visto como tautológico, Policarpo é, então, a personagem escolhida por Lima para centralizar as atenções de sua obra. Em 1916, o crítico Fábio Luz tenta descrever o que representaria tal figura.

Resume (Lima Barreto) em uma figura central todos os cacoetes, pensadores, inclinações e desvios de meia dúzia de individualidades conhecidas e fúteis, pavoneando-se de sábios, letrados, poetas e gênios, e faz girar, em torno dessa representação de um momento social, outras e muitas personagens representativas da toleima e da presunçosa vaidade da nossa misturada sociedade, em um período da lenta constituição do tipo nacional definitivo que se vai desenvolvendo e surgindo da mescla das raças (LUZ, 1916, p. 1).

Como ressaltado pelo crítico Fábio Luz, o século XIX foi um período de efervescência científica, em que se buscava uma essência nacional. Ressalta-se, nesse sentido, o trabalho de Euclides da Cunha, em Os sertões, e a exaltação de figuras como a do historiador francês Hippolyte Taine, admirado tanto por Euclides quanto por Lima, e a do naturalista britânico Charles Darwin, cujo nome é citado três vezes em $O$ triste fim de Policarpo Quaresma.

Policarpo viveu em uma época de transição política: era o fim do Império e o início da República. Estudava muito sobre o Brasil, e seu patriotismo ingênuo fez com que se tornasse "extravagante e bizarro" aos olhos de seus conterrâneos (PÓVOA, 1983, p. 19). Propõe, primeiro, tornar o tupi-guarani a língua oficial do país, mas acaba ridicularizado e tratado como louco pela população. Depois disso, tem a ideia de valorizar a cultura nacional investindo na agricultura e, por fim, decide se alistar para defender o regime de Floriano Peixoto durante a Revolta Armada. Após o fim do conflito, há uma perseguição violenta aos derrotados, contra a qual o major se posiciona e, por isso, escreve uma carta a Peixoto mostrando sua opinião sobre o ocorrido, o que o leva à prisão e, em seguida, à morte:

E que tinha feito de sua vida? Nada. Levara toda ela atrás da miragem de estudar a Pátria, por amá-la e querê-la muito, no intuito de contribuir para a sua felicidade e prosperidade. Gastara a sua mocidade nisso, a sua virilidade também; e, agora que estava na velhice, como ela o 
recompensava, como ela o premiava, como ela o condecorava? Matando-o. [...] Desde dezoito anos que o tal patriotismo o absorvia e por ele fizera a tolice de estudar inutilidades. [...] O tupi encontrou a incredulidade geral, o riso, a mofa, o escárnio; e o levou à loucura. Uma decepção. E a agricultura? Nada. As terras não eram ferazes e ela não era fácil como diziam os livros. Outra decepção. E, quando o seu patriotismo se fizera combatente, o que achara? Decepções. Onde estava a doçura de nossa gente? [...] A sua vida era uma decepção, uma série, melhor, um encadeamento de decepções. A pátria que quisera ter era um mito; era um fantasma criado por ele no silêncio do seu gabinete (BARRETO, 2006, p. 199).

Para Schwarcz, a figura de Policarpo é, então, construída por uma "série de desencantos: com a política e os políticos, com os livros, com o Brasil" (SCHWARCZ, 2017, p. 306). Em seu diário íntimo, Lima descreve a personagem da seguinte forma: "Policarpo Quaresma. Ideia que mata. A decepção. O prêmio" (BARRETO, 1900-1904, p. 66).

\section{4) Antônio Conselheiro e Policarpo Quaresma: as personagens 'loucas'}

As duas personagens da literatura brasileira surgiram de autores críticos da realidade social. Por um lado, Euclides da Cunha apontou falhas da ciência e do próprio modelo republicano implantado no Brasil. Por outro, Lima Barreto era uma figura emblemática que se preocupou com as desigualdades sociais, a corrupção e o racismo presentes na sociedade brasileira. Os dois autores vão usar a literatura como forma de conscientização social, colocando foco na "questão nacional” (GERMANO, 1995, p. 42). Assim como Lima, Euclides também rejeita a violência no governo de Floriano Peixoto e, segundo Ventura, a visão de Canudos sitiada era uma continuação do 'fantasma' que seguia Cunha desde que presenciara a Revolta Armada (VENTURA, 2003, p. 172), movimento no qual Policarpo esteve envolvido.

Apesar de ambos terem ressalvas à visão cientificista presente na época, os dois parecem segui-la na medida em que tentam fornecer ao leitor algumas explicações sobre influências do meio que teriam corroborado a formação do caráter das personagens. Por conta disso, Cunha procura apresentar a história de Conselheiro e dizer que este foi "um documento raro de atavismo", que, devido a sua "constituição mórbida", interpretou “caprichosamente as condições objetivas" (CUNHA, 1973, p. 121).

Evitada a intrusão dispensável de um médico, um antropologista encontrá-lo-ia normal, marcando logicamente certo nível da 
mentalidade humana, recuando no tempo, fixando uma fase remota da evolução. $\mathrm{O}$ que o primeiro caracterizaria como caso franco de delírio sistematizado, na frase persecutória ou de grandezas, o segundo indicaria como fenômeno de incompatibilidade com as exigências superiores da civilização - um anacronismo palmar, a revivescência de atributos psíquicos remotíssimos. Os traços mais típicos do seu misticismo estranho, mas naturalíssimo pra nós, já forma, dentro de nossa era, aspectos religiosos vulgares. Deixando mesmo de lado o influxo das raças inferiores (CUNHA, 1973, p. 121).

Lima também tem o cuidado de explicar a história de Policarpo e ressalta que a personagem foi criada com ingenuidade, desapego da realidade e mergulhada em livros, características que fizeram com que se tornasse uma patriota ingênua (BARRETO, 2006, p. 52).

É interessante pensar ainda que tanto o profeta quanto o major eram personagens que estavam em um vão entre a elite e a 'plebe', por assim dizer, e não se encaixavam em um grupo social específico. Policarpo, por exemplo, é uma personagem de margem, como o próprio Lima Barreto era. Este não era um intelectual da academia, tampouco pode ser tachado como um total desconhecedor da 'cultura culta'. Por não ocupar esse lugar intelectualizado, era sempre criticado por seus companheiros por se envolver demais com os livros, característica que, para eles, não deveria ser própria de um homem do naipe de Quaresma. Na obra, é possível notar que, após o major propor que o tupi seja a língua Nacional, há um alvoroço na repartição não só por conta de a proposta ter sido vista como absurda, mas também por ela vir de alguém como Policarpo, um inferior.

Nos meios burocráticos, uma superioridade que nasce fora deles, que é feita e organizada com outros materiais que não os ofícios, a sabença de textos e regulamentos e a Boa caligrafia, é recebida com a hostilidade de uma pequena inveja. É como se se visse no portador da superioridade um traidor à mediocridade, ao anonimato papeleiro (BARRETO, 2006, p. 53).

Nesse sentido, Silviano afirma que o romance de Lima é um dos que melhor vai tematizar a noção de repressão ao "intelectual dissidente", pois Policarpo, além de ter atitudes patrióticas com o objetivo de mudar o Brasil de modo radical, ainda se norteia por um ideal, e, por conta disso, se levanta contra as "forças dominantes" da época em que vivia (SANTIAGO, 1982, p. 170).

De igual modo, Conselheiro é uma espécie de 'intelectual dissidente’. Ao mesmo tempo em que não era um total desconhecedor da 'cultura culta', não era aceito pela elite intelectual — no caso, o clero — por não ter passado pela academia. Corroborando essa 
ideia, Euclides cita, em Os sertões, o documento Folhinha Laemmert, que descreve as limitações do beato, apesar de sua inteligência (CUNHA, 1973, p. 129):

Assim se apresentou o Conselheiro, em 1816, na vila do Itapicuru-deCima. Já tinha grande renome. Di-lo documento expressivo publicado aquele ano, na capital do Império. "Apareceu no sertão do norte um indivíduo, que se diz chamar Antônio Conselheiro, e que exerce grande influência no espírito das classes populares servindo-se de seu exterior misterioso e costumes ascéticos, com que impõe à ignorância e à simplicidade. Deixou crescer a barba e cabelos, veste uma túnica de algodão e alimenta-se tenuamente, sendo quase uma múmia. Acompanhado de duas professas, vive a rezar terços e ladainhas e a pregar e a dar conselhos às multidões, que reúne, onde lhe permitem os párocos; e, movendo sentimentos religiosos, vai arrebanhando o povo e guiando-o a seu gosto. Revela ser homem inteligente, mas sem cultura" (BARRETO, 2006, p. 199).

Os obstáculos da não aceitação, entretanto, não calam Conselheiro; pelo contrário. Ele combate o que considerava as injustiças do período em que viveu orientado pela moral religiosa e pela busca pelo divino. A título de comparação, Policarpo também não se deixa calar, mas sua mola propulsora é outra: o nacionalismo extremo.

Nesse sentido, há ainda outra aproximação possível na medida em que ambos são retratados pelos escritores como dotados de uma certa ingenuidade. Policarpo representa uma mudança na noção abstrata para uma mais concreta de pátria, com "consistência sociopolítica e econômica". Isso ocorre porque a visão da personagem não tem compromisso fiel com a concretude dos fatos sociais e baseia seus ideais em livros (SANTIAGO, 1982, p. 168). Policarpo era metódico, honesto e viveu cerca de 30 anos em um isolamento quase completo. Esse afastamento social e o desapego da realidade, segundo Schwarcz, levaram-no a idealizar uma pátria "retirada de seus livros e da sua biblioteca" (SCHWARCZ, 2017, p. 306):

Vivendo há trinta anos quase só, sem se chocar com o mundo, adquirira
uma sensibilidade muito viva e capaz de sofrer profundamente com a
menor coisa. Nunca sofrera críticas, nunca se atirou à publicidade, vivia
imerso no seu sonho, incubado e mantido vivo pelo calor dos livros.
Fora deles, ele não conhecia ninguém; e, com as pessoas com quem
falava, trocava pequenas banalidades, ditos de todo o dia, coisas com
que a sua alma e o seu coração nada tinham que ver (BARRETO, 2006,
p. 52).

Nota-se, assim, que ele era um idealista, pois vivia afastado da realidade e, de fato, a "realidade" foi a pedra no meio do caminho de seus planos para o Brasil. Primeiro, a incompreensão do povo e mediocridade da repartição; segundo, as pragas e preços altos 
na lavoura; terceiro, um tirano travestido de salvador da Pátria. Os ideais de Policarpo se fortaleciam em pensamentos patrióticos e honestos, mas lhe faltava o conhecimento da cultura nacional e uma relação de proximidade com o povo, com as classes médias e baixas da população, assistidas por Lima em suas obras.

Antônio também é descrito como o dono de um "misticismo feroz e extravagante", cujas crenças são "ingênuas" e as tendências, "impulsivas das raças inferiores" (CUNHA, 1973, p. 120). Euclides ainda ressalta que o profeta, por conta da educação que recebeu, foi "isolado da turbulência da família", sendo tímido, tranquilo e levando uma vida extremamente correta e "calma" (CUNHA, 1973, p. 126). A personagem é retratada como uma espécie de desconhecedora da realidade, por ter uma ingenuidade e inferioridade na 'escala evolutiva'. Assim, caminhava sem rumo certo, falava pouco e vivia "indiferente à vida e aos perigos" (CUNHA, 1973, p. 128). Dessa forma, os riscos da realidade - no caso, a repressão governamental - também foram o empecilho de Conselheiro para realizar seus planos.

Ressalta-se, ainda, que as duas personagens são, antes de tudo, inconformadas. Elas não ficaram confortáveis com o contexto social em que estavam inseridas e tentaram promover mudanças sociais, mas por vias distintas. Em primeiro lugar, Policarpo vai se dirigir às autoridades, e não ao povo. Ele sabia que a "conscientização social" não seria útil para que se promovessem as transformações necessárias e, portanto, via a "política" como a única forma de pôr em prática seus planos (PÓVOA, 1983, p. 14).

[...] ele, porém, não se deixava abater, fizera pé firme, pois sentia, indispensável, necessário que toda a sua vontade, que toda a sua inteligência, que tudo o que ele tinha de vida e atividade fosse posto à disposição do governo, para então!... oh! Aproveitara os dias até para redigir um memorial que ia entregar a Floriano. Nele expunham-se as medidas necessárias para o levantamento da agricultura e mostravamse todos os entraves, oriundos da grande propriedade, das exações fiscais, da carestia de fretes, da estreiteza dos mercados e das violências políticas (BARRETO, 2006, p. 141).

Por outro lado, Conselheiro busca as massas, indo contra o governo da época. Ele é descrito como um fanático que anda "acompanhado de centenas de pessoas" (CUNHA, 1973, p.136) que atendem às ordens do líder e as cumprem. Ao mesmo tempo que o beato consegue credibilidade do povo que o seguia, é perseguido pelas autoridades. Já o major é preso por não se submeter aos governantes e ficar calado, como supostamente deveria.

É possível dizer, então, que ambas as figuras tinham ideias que não foram aceitas pelas autoridades do seu tempo, porque não faziam parte dos ideais de valorização da 
ciência, da evolução e da racionalidade. Vicente Dobroruka vai afirmar, por exemplo, que Conselheiro foi feito profeta por Cunha e que a imagem de caso de atavismo que recai sobre o beato se deve ao fato de que, para o escritor, a República seria uma forma de governo mais evoluída que a monarquia, supostamente defendida pela personagem de $O s$ sertões (DOBRORUKA, 1996, p. 10).

Desse modo, por tentarem promover mudanças sociais e por conta de sua ousadia, Conselheiro e Policarpo são condenados a finais trágicos: Policarpo é morto por criticar o governo; Conselheiro é morto durante a guerra em Canudos por ter mantido firmes os pensamentos contrários (e perturbadores) às autoridades da época. Os dois vão até as últimas consequências e morrem "sem possibilidade de defesa, sem o auxílio de ninguém", sem que pudessem ser reconhecidos por alguma das causas que defenderam, morrem "sozinhos e incompreendidos" (PÓVOA, 1983, p. 24).

\section{5) Heróis ou loucos?}

As figuras de Conselheiro e Quaresma foram vistas como loucas pelo 'olhar republicano'. O primeiro por ser considerado um caso de atavismo e inferioridade; o segundo, um idealista que era atolado em livros e vivia desconectado da realidade. Ambas as personagens são marcadas pela desordem, pela não objetividade, pela ousadia e se posicionam de forma contrária aos ideais de civilização, racionalidade e evolução presentes na época em que viveram.

Euclides e Lima passaram, na criação das personagens, o seu olhar crítico sobre a sociedade. O primeiro apresenta, por meio da figura de Antônio Conselheiro, o seu pensamento, em certa medida, contrário às teorias eugenistas da época, mostrando o povo de Canudos como mais resistente e forte que o próprio exército nacional. Ele faz ainda uma feroz crítica ao governo, cujas atitudes julgava inconsistentes e injustas. Em $O s$ sertões, Euclides denuncia o genocídio ocorrido em Canudos, no sertão da Bahia, de novembro de 1896 a outubro de 1897 . Ele chegou a tratar sobre a consolidação da República dada por meio de um golpe militar e criticou o militarismo dos governantes, bem como o autoritarismo de Floriano Peixoto. A ação do exército teria sido desordenada e improvisada, visão que se contrapunha ao ideal republicano do escritor, que, quando jovem, via o novo sistema como a salvação da pátria. Esse idealismo foi abalado, também, por conta das misérias e injustiças presenciadas em Canudos, que se manifestavam, inclusive, na figura de Conselheiro (VENTURA, 1996, p. 284-285). 
De igual modo, Lima apresenta Policarpo como pueril, inocente e recorda a importância de se traçar planos para o país que sejam calcados na realidade, no conhecimento empírico da sociedade brasileira. Há, porém, na figura do major um traço de valentia e coragem necessário para se combaterem as mazelas que afetam a nação. Até a ingenuidade e o idealismo presentes tanto no beato quanto em Quaresma foram necessários para que fossem ousados em suas ações, as quais se contrapunham ao senso comum e ao pensamento determinista. De fato, o seu afã por praticar atos grandiosos sem ter um diploma e um status social necessários para tal fez com que fossem classificados como indivíduos à margem do seu tempo, figuras dissidentes cujos pensamentos foram condenados ao estigma da loucura.

O próprio Lima Barreto, escritor negro que não ocupava um lugar de destaque na academia, foi alvo desse discurso. Em 1914, ele foi internado como um anônimo no hospício, apesar de já ser um escritor relativamente conhecido. Diagnóstico: alcoolismo. A sua vida parecia, segundo Schwarcz, corresponder às expectativas cientificistas da "teoria de degeneração" do miscigenado, o qual levaria consigo o vício das raças que o compunham e eram, portanto, intelectualmente inferiores. Não por acaso, a maioria dos casos de internação incidiam sobre pessoas pobres e negras (SCHWARCZ, 2011, p. 122123). A condição genética do escritor o tornava vítima da doutrina eugenista, visto que era negro, bêbado e tratado como pobre e malvestido. Além disso, a denúncia contra a escravidão e outras mazelas cometidas contra os negros incomodavam a elite, pois afirmava que a abolição não era a solução para o problema do racismo e da desigualdade. Esse pensamento contrapunha-se ao dessa camada social que via os exescravos como um ponto negativo para a construção do país, já que, segundo o pensamento cientificista, eram degenerados.

Se a religiosidade extrema de Conselheiro era uma característica de raças inferiores em um período de supremacia das ideias evolucionistas, tanto era a valorização da cultura indígena e do folclore brasileiro, feita por Quaresma, marca de uma civilização não evoluída. Desse modo, o profeta e o major foram tratados como loucos por não se renderem ao pensamento de sua época. No auge da racionalidade, Conselheiro e Policarpo ousaram ser 'irracionais', um acreditando no divino; o outro, em uma sociedade ideal. $\mathrm{O}$ primeiro, por exemplo, "viu a República com maus olhos", como diz Euclides, e "pregou, coerente, a rebeldia contra as novas leis" (CUNHA, 1973, p. 139). É justamente essa rebeldia, a tenacidade e a ingenuidade presentes em ambas as figuras que as levam a lutar por seus ideais até as últimas consequências. Corroborando essa ideia, Schwarcz comenta 
que há na obra de Lima uma crítica ao autoritarismo e à "repressão ao pensamento divergente, cujo destino só pode ser o manicômio, a prisão ou a morte" (SCHWARCZ, 2017, p. 306). Essa regra vale tanto para o major quanto para o beato.

Se por um lado o 'olhar republicano' queria mandar Policarpo para o hospício, Olga e Ricardo Coração dos Outros, amigos do major, viam-no como um homem corajoso que lutou pelo que acreditava (SCHWARCZ, 2017, p. 303). De igual modo, os seguidores de Conselheiro enxergavam nele não só um guia espiritual, mas uma pessoa que batalhou para que eles tivessem uma vida mais digna em meio a tantas injustiças provocadas pela evoluída e sensata República. A loucura, assim tratada, nada mais é que uma questão de ponto de vista.

Como é contado por Euclides em Os sertões, após o final da Guerra de Canudos, o crânio de Antônio Conselheiro é levado para análise. Fato curioso: o de Euclides também foi analisado depois da morte do escritor em 1909. Em artigo publicado na Revista Brazileira nesse período, Nina Rodrigues vai dizer que Conselheiro é um "simples louco" por conta da sua época ou do meio em que viveu (RODRIGUES, 1897, p. 130). No entanto, Ricardo Santos cita que, em um relatório publicado postumamente, o médico afirma que o crânio do beato é normal, sem anomalias ou traços de degenerescência (SANTOS, 1998). Diz ainda que Roquette-Pinto classifica o crânio de Euclides como "notável pela riqueza e pela complexidade das circunvoluções" (SANTOS, 1998), mesmo reconhecendo que a regra para esse estudo era falha. "Que a ciência dissesse a última palavra", escreveu Euclides. Esta, como visto, não achou no crânio de Conselheiro as "linhas essenciais do crime e da loucura" (CUNHA, 1973, p. 393) e reconheceu as dificuldades em sua própria tentativa de objetividade. Em seu diário, Lima Barreto, que era um crítico do racismo presente na sociedade brasileira, condena a própria noção de objetividade do pensamento científico ao dizer que "a capacidade mental dos negros é discutida a priori, a dos brancos a posteriori" e que "a ciência é um preconceito grego, é ideologia" (BARRETO, 1998, p. 15).

Conselheiro e Quaresma morrem, então, loucos. Loucos pelo ‘olhar republicano', já que nem mesmo a ciência conseguiu comprovar suas teorias de loucura por meios biológicos. No entanto, se para uns morrem como loucos, para outros foram heróis. Em O triste fim de Policarpo Quaresma, Olga tenta resgatar Policarpo da prisão, mas ouve um dos guardas chamando o major de traidor e bandido. Assim, prefere deixar o amigo morrer honradamente que tirá-lo da cadeia por meio de favores. Policarpo, então, morre 
como herói e não se deixa render. Assim como Canudos e seu líder, resiste "até o esgotamento completo" (CUNHA, 1973, p. 392).

\section{Referências}

BARRETO, Lima. Diário íntimo. Rio de Janeiro: Fundação Biblioteca Nacional, 19001904.

Um longo sonho de futuro: diários, cartas, entrevistas e confissões dispersas. Rio de Janeiro: Graphia, 1998.

Ltda., 2006.

O triste fim de Policarpo Quaresma. Santa Catarina: Avenida Gráfica e Editora

BOLSANELLO, Maria Augusta. Darwinismo social, eugenia e racismo "científico": sua repercussão na sociedade e na educação brasileira. Educ. rev., Curitiba, n. 12, p. 153165, Dez. 1996. Disponível em: $<$ http://www.scielo.br/scielo.php?script=sci_arttext\&pid=S010440601996000100014\&lng=en\&nrm=iso > . Acesso em: 16 nov. 2018.

BOVO, Ana Paula Martins Corrêa. Antônio Conselheiro: os vários. 2007. Dissertação, Instituto de Estudos da Linguagem, Universidade Estadual de Campinas, São Paulo.

CUNHA, Euclides da. Os sertões. São Paulo: Editora Cultrix, 1973.

DEL CONT, Valdeir. Francis Galton: eugenia e hereditariedade. Sci. stud., São Paulo, v. 6, n. 2, $\quad$ p. 201-218, Jun. 2008. Disponível em: <http://www.scielo.br/scielo.php?script=sci_arttext\&pid=S1678$31662008000200004 \& \operatorname{lng}=e n \& n r m=i s o>$. Acesso em: 16 nov. 2018.

DOBRORUKA, Vicente. O Antônio Conselheiro de Euclides da Cunha: como se faz um profeta. Rio de Janeiro: PUC-RJ, Coleção Rascunhos de História, 1996.

FREITAS, Leandro Leal de. Um século de narrativas euclidianas e conselheiristas: interpretações sobre Antônio Conselheiro. 2016. Dissertação (Mestrado), Centro de Educação e Ciências Humanas, Universidade Federal de São Carlos, São Carlos.

GERMANO, ldilva Maria Pires. Os Brasis de Euclides da Cunha e Lima Barreto. Revista de Letras, Fortaleza, v. 17, n. 1/2, p. 42-49, 1995.

LUZ, Fábio. Resenha de Livros. A época, Rio de Janeiro, 12 mar. 1916, p. 1.

MUNANGA, Kabengele. Rediscutindo a mestiçagem no Brasil: identidade nacional versus identidade negra. Petrópolis, Rio de Janeiro: Vozes, 1999.

NOVOS livros: O triste fim de Polycarpo Quaresma. A época, Rio de Janeiro, 28 fev. 1916. p. 2. 
PENNA, João Camillo. Jagunços, topologia, tipologia (Euclides e Rosa). In: FARIA, Alexandre; PENNA, João Camillo; PATROCÍNIO, Paulo Roberto Tonani do. (org). Modos da Margem. 1. ed. Rio de Janeiro: Aeroplano, 2015. p. 46-74.

PÓVOA, Dulce Maria Viana. A consciência trágica: reflexões sobre o intelectual personagem. 1983. Dissertação (Mestrado), Departamento de Letras, Pontifícia Universidade Católica do Rio de Janeiro, Rio de Janeiro.

RODRIGUES, Nina. Revista Brazileira, 1897.

SANTIAGO, Silviano. Vale quanto pesa: ensaios sobre questões político-culturais. Rio de Janeiro: Paz e Terra, 1982.

SANTOS, Ricardo Ventura. A obra de Euclides da Cunha e os debates sobre mestiçagem no Brasil no início do século XX: Os sertões e a medicina - antropologia do Museu Nacional. Hist. cienc. saude-Manguinhos, Rio de Janeiro, v. 5, supl. p. 237-253, julho 1998.

SCHWARCZ, Lilia Moritz. O Homem da Ficha Antropométrica e do Uniforme Pandemônio: Lima Barreto e a Internação de 1914. Socio. Antropol., São Paulo, v. 1. n. 1, 2011. Disponível em http://www.scielo.br/scielo.php?script=sci_arttext\&pid=S010015742007000200015. Acesso em: 03 jul. 19

Lima Barreto: triste visionário. São Paulo: Companhia das Letras, 2017, p.1-19.

SOUZA, Brenda S. Medeiros de; CÂNDIDO, Natália Gomes. O papel messiânico de Antônio Conselheiro na obra Os Sertões, de Euclides da Cunha. Revista A margem, Uberlândia, n. 10, ano 6, Jan-Jun. 2016.

VENTURA, Roberto. Euclides da Cunha e a República. Estud. av. São Paulo, v. 10, n. 26, p. 275-291, abril de 1996.

Canudos como cidade iletrada: Euclides da Cunha na urbs monstruosa. Rev. Antropol., São Paulo, v. 40, n. 1, p. 165-181, 1997.

Retrato interrompido da vida de Euclides da Cunha. São Paulo: Companhia das Letras, 2003.

\section{ANALYSING THE NONSENSICAL CHARACTERS IN LIMA BARRETO AND EUCLIDES DA CUNHA'S LITERARY WORK FROM A REPUBLICAN VIEWPOINT \\ AN APPROACH TO THE RELATIONS BETWEEN ANTONNIO CONSELHEIRO AND POLICARPO QUARESMA}

\footnotetext{
Abstract

The following study analyzes the characters of Antônio Conselheiro and Policarpo Quaresma viewed as conceptual constructions created by the authors Euclides da Cunha
} 
and Lima Barreto. The scientific context is considered to be an important element in their composition. The investigation compares peripheral characters who face death in order to achieve their goals and those killed and labeled with the stigma of madness.

\section{Keywords}

Literature. Policarpo Quaresma. Antônio Conselheiro. Lima Barreto. Euclides da Cunha. 